Int. J. Electrochem. Sci., 15 (2020) 10117 - 10128

International Journal of

ELECTROCHEMICAL

SCIENCE

www.electrochemsci.org

\title{
Sulfidation of NiCo-Layered Double Hydroxide and its Capacitance performance
}

\author{
Xiaolin Qiu, Chen Wen*, Shuhua Bai, Junwei An \\ Nanchang Institute of Technology, Nan Chang, China, 330013 \\ "E-mail: winstonewen@126.com
}

doi: $10.20964 / 2020.10 .70$

Received: 17 November 2019 / Accepted: 4 August 2020 / Published: 31 August 2020

\begin{abstract}
Nickel-cobalt layered double hydroxide (NC-LDH) and $\mathrm{Na}_{2} \mathrm{~S}$ were used as precursors and sulfur source, synthesizing a series of sulfurized products at different degrees by hydrothermal method. The structure of products was characterized by X-ray diffraction. The morphology of them was characterized by scanning electron microscopy (SEM) and transmission electron microscopy (TEM). The elemental content and valence of the products were characterized by X-ray photoelectron spectroscopy (XPS). Then the cyclic voltammetry (CV) and galvanostatic charge-discharge (GCD) to characterize the electrochemical performance of the products. The results show that when the sulfidation is incomplete, the product is $\mathrm{NC}-\mathrm{LDH} / \mathrm{Co}_{9} \mathrm{~S}_{8}$ or $\mathrm{NiCo}_{2} \mathrm{~S}_{4} / \mathrm{Co}_{9} \mathrm{~S}_{8}$ two kinds of material, while when the sulfidation is completed, the product is only $\mathrm{NiCo}_{2} \mathrm{~S}_{4}$. In addition, specific capacitance increases gradually with the increased degree of sulfidation.
\end{abstract}

Keywords: NiCo-layered double hydroxide; sulfidation; capacitance performance

\section{FULL TEXT}

(C) 2020 The Authors. Published by ESG (www.electrochemsci.org). This article is an open access article distributed under the terms and conditions of the Creative Commons Attribution license (http://creativecommons.org/licenses/by/4.0/). 